\title{
The Interaction Between Debt Policy, Dividend Policy, Firm Growth, and Firm Value
}

\author{
Akhmadi AKHMADI', Robiyanto ROBIYANTO² \\ Received: August 01, 2020 Revised: October 11, 2020 Accepted: October 15, 2020
}

\begin{abstract}
This study aims to examine the antecedent factors of debt policy on the influence of firm growth on firm value. There was a total of 19 companies involved accounting for 95 observational data from a population of 169 companies listed on the Kompas 100 Index of the Indonesia Stock Exchange from 2014 to 2018. The data were analyzed through descriptive statistics, classic assumption tests, multiple regression, and hypothesis testing. The results prove that the firm growth, proxied by asset growth or sales growth, did not have a significant influence on the debt policy. Further, there was no significant influence of debt policy on firm value when using debt ratio and also dividend policy as a control variable. In contrast, there was a positive and significant influence on the firm value when using debt to equity ratio proxy, both with or without using the control variable. Therefore, the debt policy was not proven as an antecedent on the influence of firm growth on firm value. This finding implies that there was a tendency for the company management to adopt the policy, which would increase the debt ratio to increase the investors' confidence in the stock market and investors neglect the company's dividend policy.
\end{abstract}

Keywords: Kompas 100, Indonesia Stock Exchange (IDX), Firm Value, Debt Policy, Dividend Policy

JEL Classification Code: G31, G32, G35

\section{Introduction}

One of the important factors that have been the main concern of investors is firm value - one of the financial performance indicators for public companies. A high firm value indicates the prosperity of shareholders as the higher the firm value, the more profits the investors would get in addition to the dividend in the form of capital gains from the shares owned (Nguyen et al., 2020).

Research on firm value has come from Bonaimé et al. (2014); Gregory et al. (2013); Muradoğlu and Sivaprasad (2012); Robiyanto et al. (2019); Warusawitharana (2015). However, they had not reached an established

${ }^{1}$ First Author and Corresponding Author. Associate Professor, Faculty of Economics and Business, Universitas Sultan Ageng Tirtayasa, Indonesia [Postal Address: Jl. Pakupatan, Panancangan, Serang, Banten 42124, Indonesia] Email: akhmadi@untirta.ac.id

${ }^{2}$ Assistant Professor, Faculty of Economics and Business, Satya Wacana Christian University, Indonesia.

Email: robiyanto.robiyanto@uksw.edu

() Copyright: The Author(s)

This is an Open Access article distributed under the terms of the Creative Commons Attribution Non-Commercial License (https://creativecommons.org/licenses/by-nc/4.0/) which permits unrestricted non-commercial use, distribution, and reproduction in any medium, provided the original work is properly cited. relationship as found between firm growth and firm value. Maneerattanarungrot and Donkwa (2018) found that firm growth positively and significantly influenced the firm value. However, it was not in line with a study by Hamam et al. (2020), which proved that there was an insignificant influence of firm growth on firm value.

Differences in the research results are believed to be due to other variables that establish the relationship of firm growth on firm value. Several references reveal that external funds tend to be more needed by companies with high asset growth (Kouki \& Said, 2012). Similar findings by Tongkong (2012) also confirm that debt financing was usually used for companies with high growth opportunities. Meanwhile, Hoque et al. (2014) and Hang et al. (2018) found that the debt policy had a negative and significant influence on firm value. However, Kodongo et al. (2015) and Handriani and Robiyanto (2018) proved that the debt policy did not have a significant influence on the firm value.

Based on the differences in the research results, the authors believe that increasing debt policy will also increase the firm value effectively if it is based on a very high firm growth need, which is not adequately funded by internal funding sources, and if the debt ratio is still below the optimal point. If both conditions could not be met, then an 
increase in the debt policy will tend to undermine the firm value. For these reasons, the authors intend to examine firm value influenced by firm growth by including debt policy as an antecedent variable in the research model.

\section{Literature Review}

\subsection{Signaling Theory and Pecking Order Theory}

Brigham and Houston (2012) stated that signaling theory explains good or bad information for investors to understand the company's prospects in the future. Meanwhile, Lonkani and Ratchusanti (2005) claimed that the signaling theory explains information related to the managers' funding activities that may reflect the value of company shares.

Myers and Majluf (1984) stated that the pecking order theory explains sequences of corporate preferences in choosing funding sources that prioritize internal funding sources from retained earnings. If another funding source is needed, the company will prefer external funding sources in the form of new debt and followed by the issuance of equity.

\subsection{The Influence of Firm Growth on Debt Policy}

Wu and Yeung (2012) stated that companies invest rationally and seek funding that suits their type of growth. Similarly, Kouki and Said (2012) explained that companies with high asset growth need external funding sources to fund their investment projects. Relevant research results by Acaravci (2015) and Tongkong (2012) supported that companies with high growth opportunities in the future tend to use more financing than debt. For these reasons, the first hypothesis that can be formulated is as follows:

H1: The higher the firm growth, the higher the debt policy.

\subsection{The Influence of Debt Policy on Firm Value}

Mukhibad et al. (2020) explained that higher use of debt will have a negative impact, as there will be an increase in the risk of defaults which can cause the firm value to decline. In line with this, Hoque et al. (2014) stated that the debt policy measured by the debt to equity ratio brings a negative and significant impact on the firm value measured by total debt plus equity capitalization. Other relevant studies by Aggarwal and Padhan (2017); Bharwaj (2018); Hang et al. (2018) confirmed that increased leverage ratio increasingly pressured the firm value. Thus, for these reasons, the second hypothesis that can be formulated is as follows:

H2: The higher the debt policy, the lower the firm value.

\subsection{The Influence of Dividend Policy as A Control Variable}

Yousaf et al. (2019) revealed that the dividend policy proxied by dividend yield and payout ratio had a positive and significant effect on the firm value proxied by stock price volatility. Similar findings by Kim and Kim (2020); Tyastari et al. (2017) supported that investors expected the dividend as a good signal for the company's prospect. Relevant research findings by Irandoost et al. (2013) also confirmed that the dividend policy positively and significantly influenced the firm value.

Other relevant studies by Hunjra et al. (2014); Tahir et al. (2020); Zakaria et al. (2012) found that the firm value would be maximized by a high dividend payout ratio. Therefore, the third hypothesis that can be formulated is as follows:

H3: If the company pays a dividend, the higher the firm value.

\section{Research Methods}

\subsection{Population and Sample}

The population of this study involved 169 companies listed on the Kompas 100 index from 2014 to 2018. There was a total of 19 companies as the samples selected using purposive sampling technique with the following criteria: met requirements as companies listed on Kompas 100 index and never delisted from 2014 to 2018, and presented complete financial data concerning the variables observed during the observation period.

\subsection{Variables}

The observed variables include firm value as an independent variable, measured by market stock price calculated from the average market stock price per year; debt policy as an antecedent variable, measured by debt ratio - a ratio between total liability and the book value of asset and debt-to-equity ratio - a ratio between total debt and shareholders' equity; firm growth as a dependent variable, measured by asset growth and sales growth; and dividend policy as a control variable using dummy, measured by dividend (divpayer) - where 1 indicates divpayer, and 0 indicates non-divpayer.

\subsection{Data}

The observational data collected was panel data (pooling data) about the observed variables from 19 companies listed and never delisted themselves on Kompas 100 index of Indonesia Stock Exchange in the period of 2014-2018. Therefore, based on the pooling data, there was a total of 95 
observational data (n) used. The observational data collection was done through a documentation research technique. There were several data centers, such as the Indonesian Capital Market Directory (ICMD).

\subsection{Technique of Analysis}

The data was analyzed into two parts. First, a descriptive analysis was done to understand the data distribution, including mean, median, maximum value, minimum value, and standard deviation of the observed variables. The parameters used were descriptive. Second, an inferential analysis was done for decision-making, consisting of 1) meeting indices of the goodness of fit model using a classic assumption test, which includes normality, multicollinearity, heteroscedasticity, and autocorrelation test; 2) a partial hypothesis test using t-test; 3) an antecedent factor test. The data analysis was used to examine the following model:

$$
\begin{aligned}
& \mathrm{AG}=\beta \mathrm{o}+\beta 1 \mathrm{DR}+\varepsilon \\
& \mathrm{LogAVP}=\beta \mathrm{o}+\beta 1 \mathrm{DR}+\beta 2 \text { Divpayer }+\varepsilon \\
& \mathrm{SG}=\beta \mathrm{o}+\beta 1 \mathrm{DER}+\varepsilon \\
& \mathrm{LogAVP}=\beta \mathrm{o}+\beta 1 \mathrm{DER}+\beta 2 \text { Divpayer }+\varepsilon
\end{aligned}
$$

$\begin{array}{ll}\text { Note: } & \\ \text { AG } & : \text { Assets Growth } \\ \text { SG } & \text { : Sales Growth } \\ \text { DR } & \text { : Debt Ratio } \\ \text { DER } & \text { : Debt to Equity Ratio } \\ \text { LogAVP } & \text { : Log Average Stock Price } \\ \text { Divpayer } & : \text { Dividend payer } \\ \varepsilon & : \text { error term }\end{array}$

\section{Results and Discussion}

\subsection{Descriptive Statistics}

The distribution of observational data - concerning the asset growth, sales growth, dividend policy, debt ratio, debt to equity ratio and average stock price, measured by the descriptive statistics parameters - shows that the average asset growth of $12.94 \%$ and sales growth of $2.62 \%$. Meanwhile, the average debt ratio and debt-to-equity ratio are 0.59 times and 2.9 times, respectively. Also, the average stock price is IDR3,060.40. The maximum value of asset growth and sales growth is at the level of $164.17 \%$ and $115.54 \%$, respectively, while their minimum value is at the level of $10.35 \%$ and $-116.15 \%$, respectively. Further, the maximum value of debt ratio and debt-to-equity ratio is at the level of 0.92 times and 11.40 times, and the minimum value is at the level of 0.18 times and 0.22 times. Next, the maximum value of the average stock price is IDR11,250 and the minimum value is IDR70 (see Table 1.).

The standard deviation value for each research variable for asset growth and sales growth is $20.05 \%$ and $31.37 \%$, respectively. Meanwhile, the debt ratio and debt-to-equity ratio are 0.49 times and 0.22 times, respectively. Besides, the average stock price is IDR3,060.40.

\subsection{Classic Assumption Test}

This test is a requirement to use a regression equation, which aims to meet the indices of the goodness of fit of the regression equation that will be developed. The test includes normality, multicollinearity, heteroscedasticity, and autocorrelation test.

\subsubsection{Normality Test}

A normality test on the regression model developed using the Kolmogorov-Smirnov parameters using 95 observational data shows asymp.sig (2-tailed) value of 0.001 , so that the data distribution of the regression equation contains abnormal symptoms.

Next, the observational data was transformed by dropping several data whose values are under the average (outlier). After several trials and errors, there was a total of new 41 observational data after dropping 54 outliers. The data were tested for its normality using the KolmogorovSmirnov parameters and shows asymp.sig (2-tailed) value of 0.200 , making the data to be normally distributed.

Table 1: Descriptive Statistics

\begin{tabular}{|l|c|c|c|c|c|}
\hline & N & Minimum & Maximum & Mean & Std. Deviation \\
\hline assets growth & 95 & -10.35 & 164.17 & 12.9406 & 20.04918 \\
\hline sales growth & 95 & -116.15 & 115.54 & 2.6217 & 31.36527 \\
\hline div policy & 95 & .00 & 1.00 & .6105 & .49022 \\
\hline debt ratio & 95 & .18 & .92 & .5926 & .22139 \\
\hline debt to equity ratio & 95 & .22 & 11.40 & 2.9462 & 3.03683 \\
\hline average stock price & 95 & 70.00 & 11250.00 & 2803.4579 & 3060.40057 \\
\hline
\end{tabular}

Source: ICMD, processed. 


\subsubsection{Multicollinearity Test}

The next requirement to use a multiple regression equation was that among independent variables must not have a significant relationship, thus a multicollinearity test was needed. The test was done by using the VIF parameter. The VIF value of all variables ranges from $1.253-4.884$, which is lower than 10 and is in line with the required value. Therefore, the result shows no multicollinearity in the regression equation. The result of the VIF can be seen in Table 2.

\subsubsection{Heteroscedasticity Test}

The regression equation needed to be examined to understand whether there was an inequality of variance from the residuals of one observation to another. If this happened, it would fail to meet the requirements used for the regression equation. Therefore, a heteroscedasticity test was done by using the Glejser test. The result of the Glejser test can be seen in Table 3. None variable has a significant effect on the absolute error. Thus, this shows no symptoms of heteroscedasticity either in the regression model.

\subsubsection{Autocorrelation Test}

In the multiple regression, it was necessary to examine a test to understand whether, in the regression model, the observation data was strongly influenced by the previous period at a certain time. If this happened, then it failed to meet the requirements to use the regression equation. For this purpose, an autocorrelation test was done by using the Durbin Watson (DW) parameter. The Durbin Watson parameter is 1.770. Using 41 observational data and a significance level of $5 \%$, the value of $\mathrm{dl}=1.430, \mathrm{du}=1.615$, and $4-\mathrm{du}=2.385$. Thus, the Durbin Watson value is in the area of $\mathrm{dl}<\mathrm{DW}<$ 4 -du or $1.340<1.770<2.385$, which shows no symptoms of autocorrelation in the regression model.

\subsection{Hypothesis Testing}

\subsubsection{The Influence of Firm Growth on Debt Policy}

Table 4 shows the result of regression analysis regarding the influence of firm growth on debt policy. Both independent variables, i.e., asset growth and sales growth do not have a significant influence on the debt policy. The same result was also found on the analysis of the influence of firm growth on debt to equity ratio, which is shown in Table 5. Based on these results, the first hypothesis that stated the higher the firm growth, the higher the debt policy, is rejected.

The test result shows that both asset growth and sales growth have no significant influence on the debt ratio or the debt-to-equity ratio, which is not in line with what the authors estimated earlier. This result is in contrast to Kouki and Said (2012) who found that companies with high asset growth are in a more need for external sources from debt to fund the investment projects. Similarly, the result is not consistent with Acaravci (2015) and Tongkong (2012) who suggested that companies with a high growth prospect tended to use financing from debt.

Table 2: VIF Parameter

\begin{tabular}{|l|c|}
\hline Variable & VIF \\
\hline assets growth & 1.253 \\
\hline sales growth & .326 \\
\hline div policy & 1.259 \\
\hline debt ratio & 4.631 \\
\hline debt to equity ratio & 4.884 \\
\hline
\end{tabular}

Source: ICMD, processed.

Table 3: The Result of the Glejser Test

\begin{tabular}{|l|c|c|}
\hline Variable & $\mathbf{t}$ & Sig. \\
\hline assets growth & -.718 & .477 \\
\hline sales growth & .897 & .376 \\
\hline div policy & -2.381 & .063 \\
\hline debt ratio & .715 & .479 \\
\hline debt to equity ratio & -.442 & .661 \\
\hline
\end{tabular}

Note: The dependent variable is an absolute error

Source: ICMD, processed.

Table 4: The Result of Regression Analysis Regarding the Influence of Firm Growth on Debt Policy

\begin{tabular}{|l|c|c|c|}
\hline & Coefficient & $\mathbf{t}$ & Sig. \\
\hline Constant & .613 & 16.381 & .000 \\
\hline Asset Growth & .002 & .486 & .630 \\
\hline Sales Growth & .000 & -.206 & .838 \\
\hline
\end{tabular}

Note: The dependent variable is Debt Ratio Source: ICMD, processed.

Table 5: The Result of Regression Analysis Regarding the Influence of Firm Growth on Debt to Equity Ratio

\begin{tabular}{|l|c|c|c|}
\hline & Coefficient & $\mathbf{t}$ & Sig. \\
\hline Constant & 2.303 & 5.578 & .000 \\
\hline Asset Growth & .045 & 1.188 & .242 \\
\hline Sales Growth & -.005 & -.285 & .778 \\
\hline
\end{tabular}

Note: The dependent variable is Debt to Equity Ratio Source: ICMD, processed. 
This result implies that there was a tendency that, in adopting a policy on increasing the company growth, the company management did not rely on the funding sources that originated from debt. Thus, the increase in firm growth was not always in line with the increase in debt. It happened because in deciding to use the funding sources to sustain the firm growth, the management could use three alternatives of funding sources. First, it was retained earnings that could be used if the internal fund was highly strong while the macroeconomic condition had very high-interest rates and or the stock market was experiencing bearish (lethargy) condition that it was less feasible to use the external fund. Second, it was a debt that could be used if the internal fund was not strong enough to sustain the firm growth, while the macroeconomic condition was very supportive and there was a stimulant from Bank Indonesia in the form of a decrease in interest rate. Third, it was the new share issuance whether it was in the form of an initial public offering or the right issue. This new funding source could be used if the stock market was experiencing a bullish condition so that the capital market liquidity was very high.

\subsubsection{The Influence of Debt Policy on Firm Value}

Table 6 shows the result of regression analysis regarding the influence of debt policy on firm value. Only the debtto-equity ratio has a significant influence on the firm value, while debt policy did not have a significant impact on the firm value. However, the sign of debt-to-equity ratio's regression coefficient is positive. Based on these results, the second hypothesis that stated the higher the debt policy, the lower the firm value, is rejected.

The test result using the debt ratio proxy has no significant influence on the LogAVP (average stock price). However, there is a positive and significant influence on the LogAVP when using the debt to equity proxy. Nevertheless, the result is not in line with Hoque et al. (2014) who found that a higher debt policy had a negative influence on the firm value. Similarly, Bahreini et al. (2012) revealed that a higher leverage ratio depressed the firm value. The research result implies that there was a tendency for the investors not to consider the existing debt ratio condition of a company when they made decisions to increase or decrease the share investment.

This tendency was more likely to happen for short-term investors who were more interested in considering the stock price volatility than the issuer's fundamental conditions as the return they expected was capital gains compared to the dividend. Meanwhile, the existing debt-to-equity ratio condition tended to be the main consideration for the longterm investors in making decisions to increase or decrease the share investment. This tendency was quite reasonable as this type of investor did consider the fundamental conditions of the issuer. Further, there was also a tendency that, when the debt ratio got bigger, the investors would sell their shares as they were not sure that they would get the expected dividend. This action would reduce the average stock price of the issuer, thereby reducing the firm value.

\subsubsection{The Influence of Debt Policy on Firm Value with Dividend Policy as a Control Variable}

Table 7 shows the result of regression analysis regarding the influence of debt policy on firm value with dividend policy as a control variable. Consistent with the previous results, only the debt to equity ratio has a significant influence on the firm value, while debt policy did not have a significant impact on the firm value. Surprisingly, the dividend policy has a positive and significant effect on firm value. Based on these results, the third hypothesis that stated if the company pays a dividend, the higher the firm value, is accepted.

The test on the debt policy using the debt ratio proxy results in a sig. value of 0.558 with dividend policy as the control variable. Although it increased compared to the previous sig. value of 0.543 without the control variable of dividend policy, it shows that there is no significant influence on LogAVP. Meanwhile, the debt policy test using the debt-to-equity ratio proxy also results in a sig. value of 0.059 with dividend policy as the control variable compared to the previous sig. value of 0.037 without dividend policy as the control variable. This shows that there is a shift at a significance level. Although both have a positive and significant influence, the debt-to-equity ratio without dividend policy as the control variable has a positive and significant influence on LogAVP at the significance level of $5 \%$. Meanwhile, when using dividend policy as the control variable, the significance level changes at $10 \%$.

Table 6: The Result of Regression Analysis Regarding the Influence of Firm Growth on Debt to Equity Ratio

\begin{tabular}{|l|c|c|c|}
\hline & Coefficient & t & Sig. \\
\hline Constant & 5.242 & 5.674 & .000 \\
\hline Debt Ratio & 1.237 & .591 & .558 \\
\hline Debt to Equity Ratio & .404 & 2.165 & .037 \\
\hline
\end{tabular}

Note: The dependent variable is LogAVP.

Source: ICMD, processed.

Table 7: The Result of Regression Analysis Regarding the Influence of Debt Policy on Firm Value with Dividend Policy as a Control Variable

\begin{tabular}{|l|c|c|c|}
\hline & Coefficient & $\mathbf{t}$ & Sig. \\
\hline Constant & 4.953 & 5.681 & .000 \\
\hline Debt Ratio & 1.202 & .614 & .543 \\
\hline Debt to Equity Ratio & .343 & 1.946 & .059 \\
\hline Div Policy & .878 & 2.532 & .016 \\
\hline
\end{tabular}

Note: The dependent variable is LogAVP.

Source: ICMD, processed. 
Further, the result is not consistent with what the author expected earlier that the increase in debt ratio would increase the company's financial risk, so that it would lead to a decrease in the firm value. The research result is also in contrast to the findings by Hang et al. (2018) and Bahreini et al. (2012) who revealed that the increase in leverage ratio would depress the firm value. Similarly, the research result is not relevant to Hunjra et al. (2014); Khan and Meer (2017) who suggested that the dividend policy was a signal of good company prospect in the future and would maximize the firm value.

This finding implies that there was a tendency for the company management to adopt the policy which would increase the debt ratio compared to use other fund sources (internal fund or issuing new shares) to increase the investors' confidence in the stock market and the management believed that the investors were not sensitive to the company's dividend policy. It was possible to happen as the management assumed that the risk resulted from the increased debt ratio could still be compensated by tax savings resulting from the increased debt ratio. The current debt ratio was still believed to be below the optimal point so that the debt was still possible to be increased without concerning the decline in the investors' confidence. Meanwhile, the investors believed that, with the controllable risk, the management's policy to increase its debt ratio would provide a good prospect in the future without necessarily considering whether the company adopted the policy to distribute dividends or not.

\section{Conclusions}

The research results conclude that, in examining the influence of firm growth on debt policy, there is no significant effect on the firm value as increasing the firm growth would not always be in line with the increase in debt policy. There were two other sources, which could be used, including internal fund from retained earnings, and the external fund from equity capital.

Further, in examining the influence of debt policy on firm value, there is no significant influence when using debt ratio, but it has a positive and significant influence when using the debt-to-equity ratio proxy. Both results are different from what the authors expected earlier, which believed that there would be a negative and significant influence. Meanwhile, in examining the influence of debt policy on firm value with dividend policy as the control variable, it is found that the debt policy has a positive and significant influence on the firm value, both when the dividend policy as the control variable was included or not included in the regression model. However, the debt policy is not found to be an antecedent factor on the influence of firm growth on firm value.
This study has several limitations. It uses a relatively small sample - 19 companies listed in the Kompas 100 Index. Besides, this study uses at least two proxies for each observed variable. Future research should add more samples, which are not limited to only the Kompas 100 Index, but also other indexes in the Indonesia Stock Exchange. Using other proxies from the observed variables is also strongly recommended.

\section{References}

Acaravci, S. K. (2015). The determinants of capital structure: Evidence from the Turkish manufacturing sector. International Journal of Economics and Financial Issues, 5(1).

Aggarwal, D., \& Padhan, P. C. (2017). Impact of Capital Structure on Firm Value: Evidence from Indian Hospitality Industry. Theoretical Economics Letters, 7(4).

Bahreini, V., Baghbani, M., \& Bahreini, R. (2012). Analysis between financial leverage with the stock price and the operational performance of the accepted companies in Tehran's stock market. European Online Journal of Natural and Social Sciences, 2(3), 25-34.

Bharwaj, A. (2018). Financial Leverage and Firm's Value: A study of capital Structure of Selected Manufacturing Sector Firms in India. Working Paper.

Bonaimé, A. A., Öztekin, Ö., \& Warr, R. S. (2014). Capital structure, equity mispricing, and stock repurchases. Journal of Corporate Finance, 26, 182-200. doi:https://doi.org/10.1016/j. jcorpfin.2014.03.007

Brigham, E. F., \& Houston, J. F. (2012). Fundamentals of Financial Management. Boston, MA: Cengage Learning.

Gregory, A., Tharyan, R., \& Whittaker, J. (2013). Corporate Social Responsibility and Firm Value: Disaggregating the Effects on Cash Flow, Risk and Growth. Journal of Business Ethics, 124, 633-657. doi:https://doi.org/10.1007/s10551-013-1898-5

Hamam, M. D., Layyinaturrobaniyah, L., \& Herwany, A. (2020). Capital Structure and Firm's Growth in Relations to Firm Value at Oil and Gas Companies Listed in Indonesia Stock Exchange. Journal of Accounting Auditing and Business, 3(1), 14-28. https://doi.org/10.24198/jaab.v3i1.24760

Handriani, E., \& Robiyanto, R. (2018). Investment opportunity and industrial growth in Indonesia. International Journal of Business and Society, 19(2), 295-312.

Hang, M., Geyer-Klingeberg, J., Rathgeber, A. W., \& Stöckl, S. (2018). Measurement matters-A meta-study of the determinants of corporate capital structure. The Quarterly Review of Economics and Finance, 68, 211-225. doi:10.1016/j. qref.2017.11.011

Hoque, J., Hossain, A., \& Hossain, K. (2014). Impact of capital structure policy on value of the firm - A Study on some selected corporate manufacturing firms under Dhaka Stock Exchange. Ecoforum, 3(2). 
Hunjra, A. I., Shahzad, M., Chani, M. I., Hassan, S. u., \& Mustafa, U. (2014). Impact of dividend policy, earning per share, return on equity, profit after tax on stock prices. International Journal of Economics and Empirical Research, 2(3), 109-115.

Irandoost, R., Hassanzadeh, R. B., \& Salteh, H. M. (2013). The Effect of Dividend Policy on Stock Price Volatility and Investment Decisions. European Online Journal of Natural and Social Sciences, 2(3), 51-59.

Khan, R., \& Meer, J. K. (2017). Determinants of dividend payout ratio: A study of KSE manufacturing firms in Pakistan. IBT Journal of Business Studies, 13(1), 12-24.

Kim, T., \& Kim, I. (2020). The Influence of Credit Scores on Dividend Policy: Evidence from the Korean Market. Journal of Asian Finance, Economics and Business, 7(2), 33-42. https:// doi.org/10.13106/jafeb.2020.vol7.no2.33

Kodongo, O., Mokoaleli-Mokoteli, T., \& Maina, L. N. (2015). Capital structure, profitability and firm value: panel evidence of listed firms in Kenya. African Finance Journal, 17(1), 1-20.

Kouki, M., \& Said, H. B. (2012). Capital Structure Determinants: New Evidence from French Panel Data. International Journal of Business and Management, 7(1), 214-229. doi:https://doi. org/10.5539/ijbm.v7n1p214

Lonkani, R., \& Ratchusanti, S. (2005). Complete Dividend Signal. Working Paper.

Maneerattanarungrot, C., \& Donkwa, K. (2018). Capital structure affecting firm value in Thailand. ABAC Journal, 38(2), 133-146.

Mukhibad, H., Subowo, S., Maharin, D. O., \& Mukhtar, S. (2020). Determinants of Debt Policy for Public Companies in Indonesia. Journal of Asian Finance, Economics and Business, 7(6), 29-37. https://doi.org/10.13106/jafeb.2020.vol7.no6.029

Muradoğlu, Y. G., \& Sivaprasad, S. (2012). Capital structure and abnormal returns. International Business Review, 21(3), 328341. doi:https://doi.org/10.1016/j.ibusrev.2011.03.007

Myers, S. C., \& Majluf, N. S. (1984). Corporate financing and investment decisions when firms have information that investors do not have. Journal of Financial Economics, 13(2), 187-221. https://doi.org/10.1016/0304-405X(84)90023-0

Nguyen, L. T., Nguyen, A. H. V., Le, H. D., Le, A. H., \& Truong, T. T. V. (2020). The Factors Affecting Corporate Income Tax Non-Compliance: A Case Study in Vietnam. Journal of Asian Finance, Economics and Business, 7(8), 103-115. https://doi. org/10.13106/jafeb.2020.vol7.no8.103

Robiyanto, R., Putra, A. R., \& Lako, A. (2019). The effect of corporate governance and intellectual capital toward financial performance and firm value of socially responsible firms. Contaduría y Administración, 66(1), 1-29. http://dx.doi. org/10.22201/fca.24488410e.2021.2489

Tahir, H., Rahman, M., \& Masri, R. (2020). Do Board Traits Influence Firms' Dividend Payout Policy? Evidence from Malaysia. Journal of Asian Finance, Economics and Business, 7(3), 87-99. https://doi.org/10.13106/jafeb.2020.vol7.no3.87

Tongkong, S. (2012). Key factors influencing capital structure decision and its speed of adjustment of Thai listed real estate companies. Procedia - Social and Behavioral Sciences, 40, 716-720. doi:https://doi.org/10.1016/j.sbspro.2012.03.254

Tyastari, T. T. D., Rosidi, R., \& Saraswati, E. (2017). Dividend Policy and Corporate Value (A Meta-Analysis). Jurnal Keuangan dan Perbankan, 21(3).

Warusawitharana, M. (2015). Research and development, profits, and firm value: A structural estimation. Quantitative Economics, 6(2), 531-565. https://doi.org/10.3982/QE282

Wu, X., \& Yeung, C. K. A. (2012). Firm growth type and capital structure persistence. Journal of Banking \& Finance, 36(12), 3427-3443. https://doi.org/10.1016/j.jbankfin.2012.08.008

Yousaf, I., Ali, S., \& Hassan, A. (2019). Effect of family control on corporate dividend policy of firms in Pakistan. Financial Innovation, 5(1). doi:10.1186/s40854-019-0158-9

Zakaria, Z., Muhammad, J., \& Zulkifli, A. H. (2012). The impact of dividend policy on the share price volatility: Malaysian construction and material companies. International Journal of Economics and Management Sciences, 2(5), 1-8. 